\title{
Dietary habits of a large, long-lived endangered Australian percichthyid, the eastern freshwater cod Maccullochella ikei
}

\author{
Gavin L. Butler ${ }^{1, *}$, Ian J. Wooden ${ }^{2}$ \\ ${ }^{1}$ Department of Primary Industries NSW, Grafton Fisheries Centre, PMB 2, Grafton, New South Wales 2460, Australia \\ ${ }^{2}$ Department of Primary Industries NSW, Narrandera Fisheries Centre, PO Box 182, Narrandera, New South Wales 2700, \\ Australia
}

\begin{abstract}
The diet of the endangered eastern freshwater cod Maccullochella ikei Rowland, 1985 was studied over 2 consecutive years in the Mann and Nymboida River system, Australia, to determine summer and winter feeding habits. Food items were extracted using non-destructive gastric lavage. In total, $268 \mathrm{M}$. ikei were gut-flushed over the $2 \mathrm{yr}$ of the study; 191 contained at least 1 food item. A large variety and broad size range of items were recovered, from small aquatic insects to relatively large terrestrial animals. We found significant differences between the food items consumed by M. ikei in summer and winter. Seasonal differences related to the increased occurrence of crustaceans, small fish and terrestrial animals in the diet of $M$. ikei during winter, and more aquatic insects and molluscs in summer. Food items differed significantly among size classes, with larger $M$. ikei consuming fewer crustaceans and more large fish and terrestrial animals. Our study revealed that $M$. ikei displays high plasticity in seasonal dietary habits, changes diet and foraging tactics as it grows, and appears to not always consume what would be considered optimal forage. While many of the issues surrounding the conservation of $M$. ikei initially appear to be localised, aspects of its biology including its dietary habits also have context across broader scales.
\end{abstract}

KEY WORDS: Gastric lavage · Freshwater cod · Ontogeny $\cdot$ Season $\cdot$ Optimal forage

\section{INTRODUCTION}

The study of diets is essential for the effective management and conservation of animal species (Duffy \& Jackson 1986, Santos et al. 2001). As with many aspects of biological research, defining the precise diet of an individual species can be difficult, as significant variation can occur both within and among populations. While the reasons for these dietary variations are numerous, examples of where it may occur include: when populations are widely distributed or are geographically separated (e.g. Szepanski et al. 1999, Stehlik \& Meise 2000, Olson et al. 2003, Munro et al. 2006); where there is an ontogenetic shift in dietary habit as an individual grows (e.g. Wassenaar \& Hobson 1998, Knutsen et al. 2001, Renones et al. 2002, Drewe et al. 2004); where individuals within a population move from one area to another such as when undertaking large-scale migrations (e.g. Williams \& Karasov 2001, Joyce et al. 2002, Sakuragi et al. 2003); or where the forage of choice may not be available, facilitating a switch to alternative food types, including reasons such as seasonal availability of different food types (e.g. Munkittrick \& Dixon 1989, Yamagiwa et al. 1994, Specziar et al. 1998).

A lack of preferred or optimal forage can at times be a contributing factor in population declines (Merrick et al. 1997, Boonstra et al. 1998, Reid \& Croxall 
2001). Unlike many threats, the effects of low food abundance can be slow and insidious and as such can often be difficult to detect. This can be particularly problematic when working with threatened species, as numbers within imperilled populations can already be at critically low levels when an issue is eventually recognised, making the collection of meaningful numbers of samples even more difficult. In the case of threatened fish species, this has traditionally posed an even greater issue, as conventional fisheries dietary assessments often involved euthanising large numbers of individuals to remove stomachs and evaluate their contents (Bowen 1996). In recent times, sampling techniques such as gastric

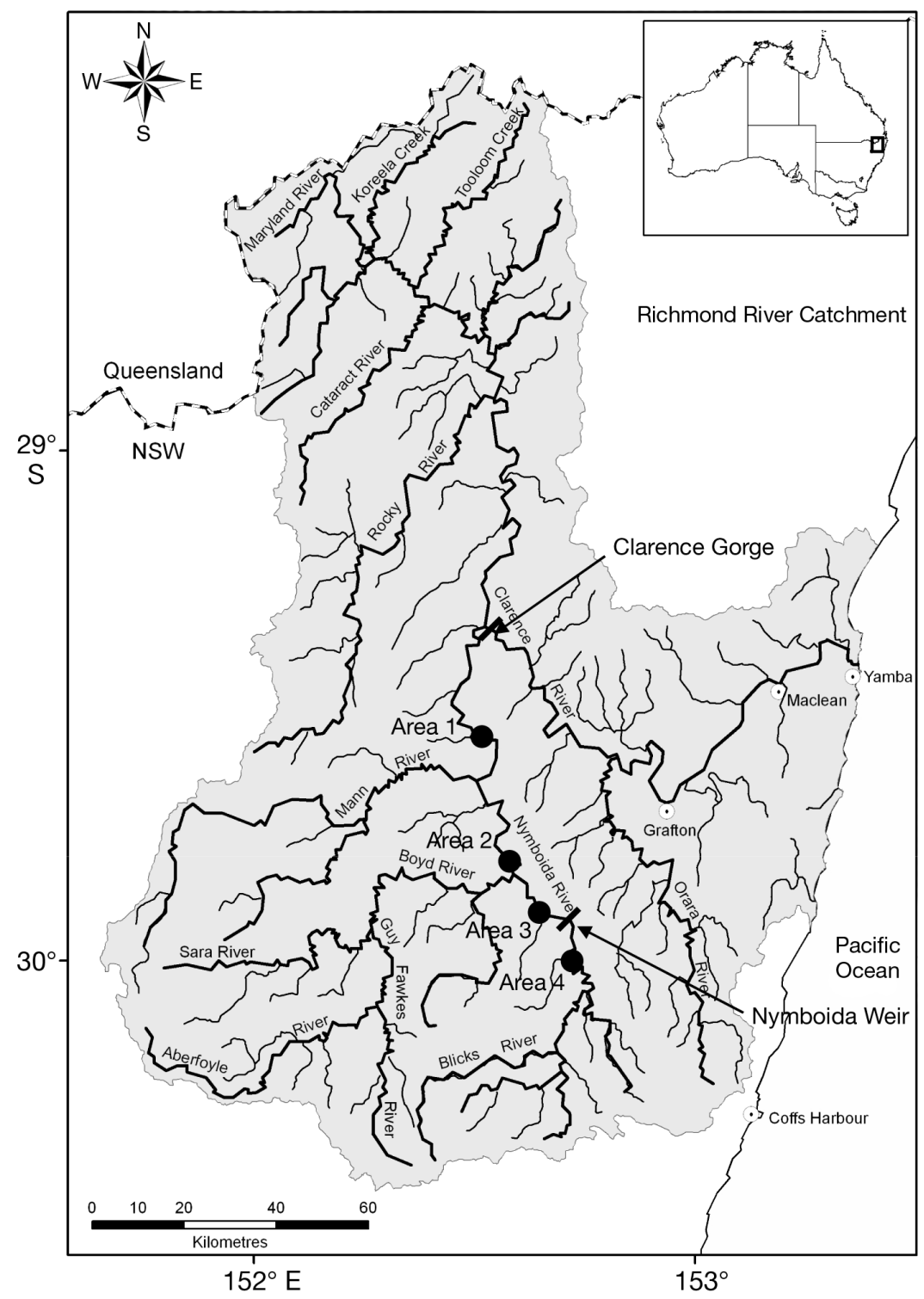

Fig. 1. Clarence River system showing the Mann and Nymboida River system and mid-points of the 4 areas where Maccullochella ikei were sampled lavage have been developed that allow the collection of meaningful dietary information, while at the same time aiming to minimise the impact on the population being studied (Petridis \& O'Hara 1988, Meretsky et al. 2000, Wanner 2006). However, despite the development of these less destructive techniques, the dietary habits of many fish species still remain poorly understood.

The eastern freshwater cod Maccullochella ikei Rowland, 1985 is an endangered fish species native to the Clarence and Richmond River systems of northern New South Wales, Australia (Fig. 1). Prior to European settlement, $M$. ikei was distributed from the large slow-flowing lowland sections through to the highland streams and rivers of both systems (Rowland 1993). However, a major decline in abundance and distribution occurred in both populations throughout the 20th century. By the 1970s, only 1 self-sustaining population remained in an isolated sub-catchment of the Clarence River (Rowland 1985, 1993). A number of recovery actions have been subsequently implemented to assist in recovering the species, including a year-round prohibition on targeting and keeping $M$. ikei throughout its original range, a complete fishing closure in the Mann and Nymboida River system over the breeding season and restocking and habitat restoration programs (Rowland 1989, Talbot et al. 2004, Anonymous 2006, Butler \& Rowland 2009). Whilst these actions have resulted in a general increase in the range and abundance of $M$. ikei, a number of processes continue to threaten the long-term conservation of the species (Anonymous 2004).

Maccullochella ikei is thought to be among the top predators in the streams and rivers they inhabit (Rowland 1993). Based largely on anecdotal reports from anglers, the diet of similar species such as the congeneric Murray cod Maccullochella peelii (Mitchell), and on a small number of randomly collected samples, Rowland (1996) suggested that the species' diet most likely consisted of a combination of larger prey such as fish, crustaceans, frogs, aquatic birds and terres- 
trial items such as snakes. A study by Butler (2001), in which a small number of samples were collected from the Mann and Nymboida Rivers, reported that M. ikei displayed high degrees of plasticity in forage selection, possibly due to the seasonal availability of different food types. However, there has been no detailed study of the diet of $M$. ikei on larger temporal and spatial scales. A general paucity of information regarding $M$. ikei's natural history including its dietary habits is listed as a key issue in the species recovery plan (Anonymous 2004). The aim of the present study was to determine the spatial, seasonal and ontogenetic dietary habits of M. ikei in the Mann and Nymboida River system. Because of the threatened status of the species, non-destructive sampling techniques were used to collect all samples.

\section{MATERIALS AND METHODS}

\section{Study area}

The Mann and Nymboida River system makes up the largest sub-catchment of the Clarence River, located on the north-eastern coast of New South Wales, Australia (Fig. 1). The system is considered relatively pristine, and is typified by long slow-flowing pools, separated frequently by waterfalls, cascades, rapids and riffles (Ferguson et al. 1999, Butler 2001). Both rivers are largely unregulated, with only the Nymboida Weir diverting any significant water from the system. The Nymboida Weir was constructed in 1924 and raised to its current height of $4.38 \mathrm{~m}$ in 1937 to meet both the growing requirements of a hydro-electric power station and to provide potable water to the nearby towns of Grafton, Maclean and Lawrence (Anonymous 2000). Recent upgrades to the potable water supply system have seen an increase in the levels of extraction to supply other towns on the north coast, as well as the construction of a large off-stream storage dam that is also to be filled from the Nymboida River.

Maccullochella ikei were sampled from 4 areas in the Mann and Nymboida River system during winter and summer each year in 2004 and 2005 (Fig. 1). Each area was a minimum of $20 \mathrm{~km}$ apart. There were a number of flow-dependent natural fish barriers between each area such as waterfalls $(<3 \mathrm{~m})$ and large cascades, as well as long shallow riffle sections. The Nymboida Weir also restricted fish passage between Area 3 and Area 4 under basal flows (Fig. 1).

\section{Sampling methods}

The stomach contents of Maccullochella ikei were non-destructively evacuated using a modified gastric lavage technique similar to that described by Kamler \& Pope (2001). M. ikei were captured using an electrofishing boat, fitted with a Smith-Root GPP 7.5 H/L electrofisher unit, operated at $1000 \mathrm{~V} \mathrm{DC}, 120 \mathrm{~Hz}$, $10 \%$ duty cycle and producing on average 2 to 4 amps. Sampling was undertaken in daylight hours (08:00 to $17: 00 \mathrm{~h})$, with 2 areas generally sampled each day. Collecting samples from $M$. ikei during this period was considered the optimal time, as the species is thought to feed primarily at night (Butler 2009), and given that most carnivorous fish species take $>24 \mathrm{~h}$ to digest food (Bowen 1996), this period would therefore effectively include the previous night's intake.

Following recovery from electro-shocking, individuals were anaesthetised in a $60 \mathrm{l}$ bin containing $100 \mathrm{mg} \mathrm{l}^{-1}$ of benzocaine (ethyl- $p$-aminobenzoate; Sigma Aldrich). Once righting reflex was lost, a tracheal tube was passed through the oesophagus of the fish and into the stomach. A small hand pump was then used to introduce water into the stomach, with a light massage applied to the abdomen to assist in back-flushing food items out of the mouth. Forceps were used to remove food items that could be seen through the mouth, but were too large to be flushed or were caught in the oesophagus. Generally, the majority of items were easily back-flushed or removed with little evidence of internal physical trauma. Samples were immediately preserved in $70 \%$ ethyl alcohol for later examination. Individuals were then weighed to the nearest $g$ and measured (total length, TL) to the nearest $\mathrm{mm}$ before being revived. All Maccullochella ikei over $280 \mathrm{~mm}$ were also tagged with $11 \mathrm{~mm}$ glass Trovan ID100 passive integrated transponder (PIT) tags (Microchips Australia) before release. PIT tags were inserted in the epaxial muscle between the anterior of the dorsal spine and the lateral line (Nielsen 1992).

\section{Identification and analyses of food items}

The extracted stomach contents of Maccullochella ikei were viewed directly or with the aid of a dissecting microscope. Each item was identified to the lowest taxon possible or where positive identification could not be made, recorded as unidentifiable. Hair samples and bones were used to help identify mammals. Counts and wet weights of individual prey 
items were recorded for each fish. Wet weight was estimated either directly to the nearest $0.01 \mathrm{~g}$ when items were complete, or where an item was not whole it was compared to a reference set of complete specimens and this was taken as the item's weight when first ingested (Bowen 1996).

Three diet indices were used to quantify the diet of Maccullochella ikei: frequency of occurrence, proportion by number $\left(N_{i}\right)$ and proportion by weight $\left(W_{i}\right)$ (Chipps \& Garvey 2007). This approach allowed for an overall description of the diet, as well as quantifying the relative importance of individual food items. To allow further statistical comparisons, indices were calculated for each fish separately, as such treating the individual as the sampling unit rather than the population as a whole (Chipps \& Garvey 2007). Because of the relatively small numbers of some taxa, individual items were combined into 9 broader groups for statistical analyses (Falautano et al. 2007, Platell et al. 2007). Groupings were based either on taxonomic (crustaceans, molluscs, reptiles and amphibians), size (fish less or greater than $100 \mathrm{~mm}$ in length) or ecological characteristics (terrestrial animals, aquatic insects and terrestrial insects).

Non-parametric multivariate analysis of variances (PERMANOVA) was used to identify differences among years, seasons and sites, for both $W_{i}$ and $N_{i}$ (PRIMER 6 and PERMANOVA, Anderson et al. 2008). PERMANOVA was also used to compare diet among size classes of all Maccullochella ikei sampled ( $\leq 350 \mathrm{~mm} ; 351$ to $450 \mathrm{~mm} 451$ to $550 \mathrm{~mm}_{i} \geq 551 \mathrm{~mm}$ ) to distinguish ontogenetic shifts in dietary habit. For all analyses, the data were initially fourth-root transformed, and the results were used to produce a similarity matrix employing the Bray-Curtis resemblance measure. All tests were considered significant at $\mathrm{p}<$ 0.05. Post-hoc pairwise comparisons were used to determine which groups differed within factors where differences were determined by PERMANOVA. Similarity percentages (SIMPER) tests were used to identify individual prey species contributions to average dissimilarities among factor groups.

Table 1. Maccullochella ikei. Sample size and total length and weight (means $\pm \mathrm{SE}$, with range in parentheses) of cod collected for dietary assessment

\begin{tabular}{|lccc|}
\hline & $\begin{array}{c}\text { Numbers } \\
\text { in sample }\end{array}$ & $\begin{array}{c}\text { Total length } \\
(\mathrm{mm})\end{array}$ & $\begin{array}{c}\text { Weight } \\
(\mathrm{g})\end{array}$ \\
\hline Winter 2004 & 69 & $424 \pm 14(173-903)$ & $1266 \pm 178(60-11330)$ \\
Summer 2004 & 62 & $428 \pm 11(170-678)$ & $1119 \pm 91(49-4156)$ \\
Winter 2005 & 83 & $454 \pm 14(132-955)$ & $1565 \pm 239(27-14100)$ \\
Summer 2005 & 54 & $434 \pm 15(134-650)$ & $1216 \pm 101(27-3520)$ \\
\hline
\end{tabular}

\section{RESULTS}

\section{Length frequency of Maccullochella ikei}

The stomachs of 268 Maccullochella ikei were evacuated during the 4 sampling rounds: 116 and 152 in summer and winter, respectively. Individuals ranged from 132 to $955 \mathrm{~mm}$ in TL and from 27 to $14100 \mathrm{~g}$ in weight, with overall averages $( \pm \mathrm{SE})$ of 436 $\pm 7 \mathrm{~mm}$ and $1314 \pm 92 \mathrm{~g}$ (Table 1$)$. There was no significant difference in TL of $M$. ikei collected across samples (Kruskal-Wallis $=2.37 ; \mathrm{p}=0.49$ ) or between seasons when the 2 winter and 2 summer samples were combined (Mann-Whitney $=8783 ; \mathrm{p}=0.86$ ). Comparisons of weight were not made due to the likely seasonal differences in gonad development of individual fish (Butler \& Rowland 2008).

\section{Diet indices}

Of the 268 stomachs evacuated, 191 contained at least 1 food item. In total, 772 individual items were categorised, with a total estimated weight of $7185 \mathrm{~g}$. Items included individuals from 38 identifiable taxa, as well as 1 unidentified taxon in each of 4 categories (Table 2). The size of items recovered ranged from small aquatic insects to relatively large terrestrial animals. Individual Maccullochella ikei of all sizes consumed a wide variety and size of items. For example, a freshwater shrimp Paratya australiensis $(0.26 \mathrm{~g})$, a juvenile freshwater catfish Tandanus tandanus Mitchell (60.03 g), an introduced goldfish Carassius auratus Linnaeus (26.2 g) and an introduced common house mouse Mus musculus (12.6 g) were all recovered from 1 individual $(595 \mathrm{~mm}$ TL and 2650 g). Overall, crustaceans were the highest represented group in all 3 diet indices, and were made up primarily of the freshwater prawn Macrobrachium sp., and $P$. australiensis (Table 2). Aquatic insects were the next highest among all indices, dominated by the shrimp louse Tachaea caridophaga and the larva of the dragonfly Hemicordulia intermedia. Unidentified taxa were the highest for all indices in the small fish group, while juvenile freshwater catfish $T$. tandanus $(<200 \mathrm{~mm})$ were evacuated most frequently from the large fish. Of the terrestrial animals, $M$. musculus was the highest by frequency of occurrence and $N_{i}$ and the introduced rabbit Oryctolagus cuniculus in $W_{i}$. Other terrestrial animals 
were relatively rare, with only 1 bandicoot (Perameles or Isoodon sp., a large marsupial of the family Peramelidae), a white-tailed water rat Hydromys chrysogaster, an introduced common rat Rattus rattus, a small marsupial of the genus Antechinus or Sminthopsis sp. (family Dasyuridae), and individuals from 2 identifiable bird species (Rhipidura leucophrys and Malurus cyaneus) and 1 unidentifiable bird (Table 2). Reptiles and amphibians were the lowest groups in all 3 indices (Table 2).

\section{Seasonal differences}

There were significant differences between the summer and winter diet of Maccullochella ikei for both $N_{i}$ (PERMANOVA: $F=5.88, \mathrm{p}<0.01$, Fig. 2a) and $W_{i}$ (PERMANOVA: $F=5.38, \mathrm{p}<0.01$, Fig. $2 \mathrm{~b}$ ). SIMPER analysis revealed that the groups contribut- ing most to differences $(>9 \%)$ were crustaceans $\left(N_{i}=\right.$ $26.2 \% ; W_{i}=26.3 \%$; greater in (>) winter), aquatic insects $\left(N_{i}=20.6 \% ; W_{i}=19.4 \%\right.$; >summer $)$, molluscs $\left(N_{i}=15.2 \% ; W_{i}=15.0 \% ;>\right.$ summer $)$, small fish $\left(N_{i}=\right.$ $14.7 \% ; W_{i}=14.8 \%$; > winter) and terrestrial animals $\left(N_{i}=9.1 \% ; W_{i}=10.6 \%\right.$; >winter $)$. There was no significant difference between the diet of $M$. ikei among sites (PERMANOVA: $N_{i}: F=0.75, \mathrm{p}=0.67 ; W_{i}: F=$ $1.12, \mathrm{p}=0.35$ ), but there was a significant interaction between site and season (PERMANOVA: $N_{i}: F=2.87$, $\mathrm{p}<0.01 ; W_{i}: F=2.48, \mathrm{p}<0.01$ ). Post-hoc comparisons revealed that there were seasonal differences in all except Area 1 (pairwise test Area 1: $N_{i}: t=0.96, \mathrm{p}=$ $0.46 ; W_{i}: t=0.55, \mathrm{p}=0.86$ ). There were also significant differences in the diet of $M$. ikei between years by number (PERMANOVA: $F=4.62, \mathrm{p}<0.01$ ) but not by weight (PERMANOVA: $F=1.47, \mathrm{p}=0.22$ ). There was no significant interaction among any other combinations of factors.

Table 2. Frequency of occurrence $\left(\mathrm{O}_{i}\right)$, proportion by number $\left(N_{i}\right)$ and proportion by weight $\left(W_{i}\right)$ of prey items evacuated from Maccullochella ikei

\begin{tabular}{|c|c|c|c|c|c|c|c|}
\hline & $O_{i}(\%)$ & $N_{i}(\%)$ & $W_{i}(\%)$ & & $O_{i}(\%)$ & $N_{i}(\%)$ & $W_{i}(\%)$ \\
\hline \multicolumn{4}{|l|}{ Crustaceans } & \multicolumn{4}{|l|}{ Aquatic insects } \\
\hline Paratya australiensis & 20.32 & 26.46 & 9.66 & Hemicordulia intermedia & 9.77 & 7.96 & 7.70 \\
\hline Macrobrachium sp. & 20.85 & 12.45 & 34.13 & Hemicordulia tau & 1.85 & 1.21 & 1.42 \\
\hline Daphnia sp. & 0.26 & 9.80 & 0.24 & Hemigomphus sp. & 1.32 & 0.86 & 0.69 \\
\hline Total & 41.44 & 48.71 & 44.04 & Tachaea caridophaga & 6.07 & 4.67 & 0.66 \\
\hline \multicolumn{4}{|l|}{ Molluscs } & Sub-order Zygoptera & 0.26 & 0.17 & 0.19 \\
\hline Hyridella depressa & 3.17 & 3.26 & 1.14 & Hygrobia sp. & 0.53 & 0.35 & 0.14 \\
\hline Hyridella australis & 4.75 & 5.70 & 8.70 & Hemianax papuensis & 0.26 & 0.14 & 0.60 \\
\hline Total & 7.92 & 8.97 & 9.83 & Family Coccinellidae & 0.26 & 0.17 & 0.59 \\
\hline \multicolumn{4}{|l|}{ Fish spp. $<100 \mathrm{~mm}$} & Total & 20.32 & 15.53 & 12.00 \\
\hline Hypseleotris spp. & 2.37 & 2.13 & 1.09 & \multicolumn{4}{|l|}{ Terrestrial animals } \\
\hline Retropinna semoni & 1.85 & 2.67 & 1.70 & \multicolumn{4}{|l|}{ Mammals } \\
\hline Ambassis agassizii & 0.79 & 0.80 & 0.98 & Mus musculus & 4.23 & 4.14 & 0.68 \\
\hline Gambusia holbrooki & 0.79 & 0.40 & 1.52 & Rattus rattus & 0.26 & 0.26 & 0.22 \\
\hline Philypnodon sp. & 0.26 & 0.40 & 1.06 & Oryctolagus cuniculus & 0.26 & 0.26 & 5.95 \\
\hline Unidentified & 7.65 & 5.06 & 5.62 & Hydromys chrysogaster & 0.26 & 0.26 & 2.35 \\
\hline \multirow{2}{*}{ Total } & 13.72 & 11.46 & 11.98 & Family Dasyuridae & 0.26 & 0.26 & 0.05 \\
\hline & \multirow{2}{*}{\multicolumn{3}{|c|}{ Fish spp. $>100 \mathrm{~mm}$}} & \multicolumn{4}{|c|}{ (Antechinus or Sminthopsis sp.) } \\
\hline $\begin{array}{l}\text { Fish spp. }>\mathbf{1 0 0} \mathbf{~ m m} \\
\text { Tandanus tandanus }\end{array}$ & & & & \multicolumn{2}{|l|}{ Family Peramelidae } & 0.26 & 0.74 \\
\hline Carassius auratus & $\begin{array}{l}0.40 \\
1.85\end{array}$ & $\begin{array}{l}3.00 \\
1.93\end{array}$ & $\begin{array}{l}5.2 t \\
1.05\end{array}$ & \multicolumn{4}{|l|}{ (Perameles or Isoodon sp.) } \\
\hline Myxus petardi & 0.26 & 0.24 & 2.52 & \multicolumn{4}{|l|}{ Birds } \\
\hline Anguilla reinhardtii & 0.26 & 0.24 & 0.05 & Rhipidura leucophrys & 0.26 & 0.26 & 0.05 \\
\hline Unidentified & 0.53 & 0.24 & 0.82 & Malurus cyaneus & 0.26 & 0.26 & 0.05 \\
\hline Total & 6.33 & 6.51 & 9.72 & Unidentified & 0.26 & 0.26 & 0.12 \\
\hline \multirow{2}{*}{\multicolumn{4}{|c|}{ Reptiles }} & Total & 6.32 & 6.20 & 10.20 \\
\hline & & & & \multicolumn{4}{|l|}{ Terrestrial insects } \\
\hline Emydura macquarii & 1.32 & 1.41 & 1.40 & Delena cancerides & 0.26 & 0.13 & 0.05 \\
\hline Total & 1.32 & 1.41 & 1.40 & Super Family Acridoidea & 0.53 & 0.25 & 0.21 \\
\hline \multicolumn{4}{|l|}{ Amphibians } & Order Lepidoptera & 0.26 & 0.13 & 0.10 \\
\hline Litoria sp. & 0.26 & 0.11 & 0.37 & Order Coleoptera & 0.26 & 0.13 & 0.02 \\
\hline Juvenile frog unidentified & 0.26 & 0.11 & 0.04 & Hemigomphus sp. & 0.53 & 0.25 & 0.01 \\
\hline \multirow[t]{2}{*}{ Total } & 0.52 & 0.22 & 0.41 & Family Gryllidae & 0.26 & 0.13 & 0.02 \\
\hline & & & & Total & 2.11 & 1.00 & 0.41 \\
\hline
\end{tabular}



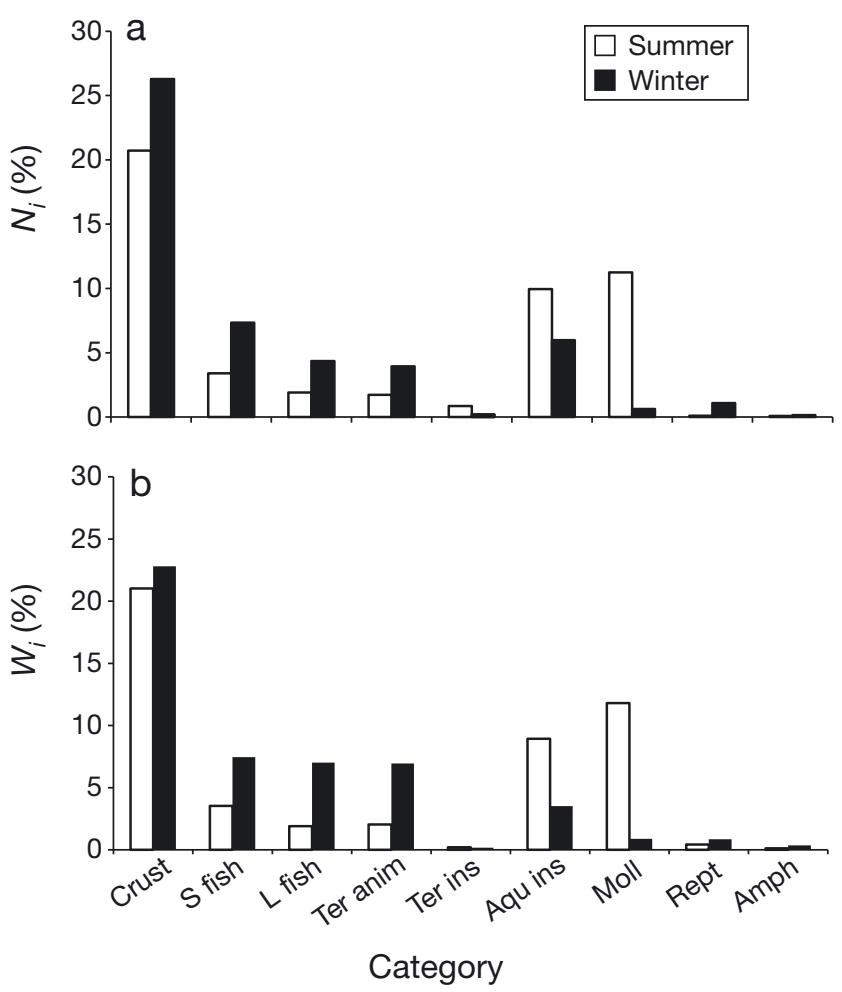

Fig. 2. (a) Proportion by number $\left(N_{i}\right)$ and (b) proportion by weight $\left(W_{i}\right)$ of prey items evacuated from Maccullochella ikei in summer and winter. Crust: crustaceans; $\mathrm{S}$ fish: small fish $<100 \mathrm{~mm}_{\text {; }} \mathrm{L}$ fish: large fish $>100 \mathrm{~mm}$; Ter anim: terrestrial animals; Ter ins: terrestrial insects; Aqu ins: aquatic insects; Moll: molluscs; Rept: reptiles; Amph: amphibians

\section{Ontogenetic dietary differences}

There were significant differences in the diet of the 4 size categories of Maccullochella ikei for both $N_{i}$ (PERMANOVA: $F=6.66, \mathrm{p}<0.01$ ) and $W_{i}$ (PERMANOVA: $F=6.12 ; \mathrm{p}<0.01)$. Post-hoc comparisons revealed significant differences between the diet of M. ikei $\geq 551 \mathrm{~mm}$ and all other size classes (pairwise tests: $\leq 350 \mathrm{~mm}: N_{i}: t=3.66, \mathrm{p}<0.01 ; W_{i}: t=3.74, \mathrm{p}<$ $0.01 ; 351$ to $450 \mathrm{~mm}: N_{i}: t=3.80, \mathrm{p}<0.01 ; W_{i}: t=3.44$, $\mathrm{p}<0.01 ; 451$ to $550 \mathrm{~mm}: N_{i}: t=3.53, \mathrm{p}<0.01 ; W_{i}: t=$ 3.33, p < 0.01), and between $M$. ikei $\leq 350 \mathrm{~mm}$ and 451 to $550 \mathrm{~mm}$ TL for $W_{i}$ (pairwise tests: $N_{i}: t=1.64$, $\mathrm{p}=0.04)$. There were no significant differences between any other groups. $M$. ikei $\geq 551 \mathrm{~mm}$ consumed fewer crustaceans (SIMPER: $N_{i} 22 \%, W_{i}>21 \%$ ), but more terrestrial animals (SIMPER: $N_{i}>12 \%, W_{i}$ $>14 \%$ ) and large fish (SIMPER: $N_{i} 14 \%, W_{i}>13 \%$ ) than the other size classes in both $N_{i}$ (Fig. 3a) and $W_{i}$ (Fig. 3b). Similarly, M. ikei 451 to $550 \mathrm{~mm}$ also consumed fewer crustaceans (SIMPER: $W_{i}=16.3 \%$ ) than M. ikei $\leq 350 \mathrm{~mm}$ in $W_{i}$ and fewer aquatic insects
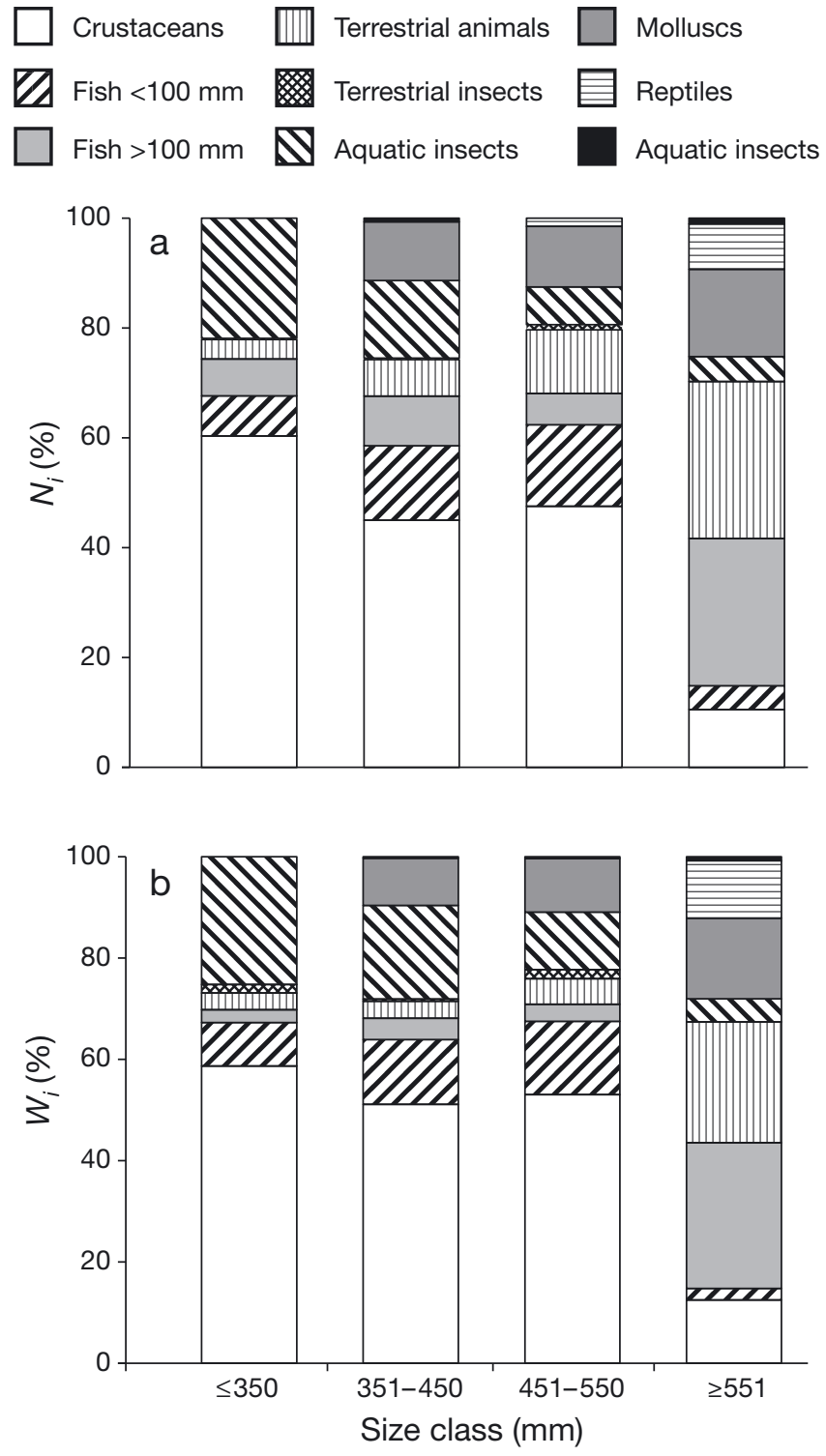

Fig. 3. (a) Proportion by number $\left(N_{i}\right)$ and (b) proportion by weight $\left(W_{i}\right)$ of prey items recovered from 4 size classes of Maccullochella ikei

(SIMPER: $W_{i}=13.6 \%$ ), but more fish $<100 \mathrm{~mm}$ (SIMPER: $W_{i}=10.5 \%$ ).

\section{Validation of techniques}

Of the 268 Maccullochella ikei sampled, 17 individuals either died as a result of the sampling techniques used ( $\mathrm{n}=12$ ) or were retained to validate evacuation techniques $(n=5)$. Deaths resulting from the sampling techniques used were for the most part related to stress from capture and handling. These fish ranged from 131 to $495 \mathrm{~mm}$ TL, with a mean of 
$316 \pm 33 \mathrm{~mm}$. Of the 17 individuals, 15 of the stomachs that were removed and dissected contained no food items. The stomachs of the 2 remaining individuals contained 1 food item each, a large incomplete Macrobrachium sp. (442 mm TL), and an intact freshwater mussel Hyridella australis (495 mm TL). Both of these individuals had been moribund prior to stomach evacuation and died shortly after the procedure was completed. The poor condition of the fish pre-flushing most likely affected the vigour of the evacuation process, with the end result being that the items were not effectively flushed out.

In total, 175 of the gut-flushed Maccullochella ikei were PIT tagged over the first 3 rounds of the study: 60, 49 and 66 in rounds 1, 2 and 3, respectively. Fish ranged from 281 to $955 \mathrm{~mm}$ TL when tagged. Of these, 28 were recaptured during the remaining 3 sampling rounds, including 26 once and 2 individuals twice. The number of days at liberty ranged from 182 to 553, with those fish recaptured ranging from 293 to $903 \mathrm{~mm}$ when tagged. All recaptured fish had increased $(n=24)$ or remained the same length $(n=4)$ while at liberty. Those individuals that grew increased in size on average by $0.014 \pm 0.002 \% \mathrm{~d}^{-1}$ of their original length.

\section{DISCUSSION}

Given the food items recovered from Maccullochella ikei in the present study, the species is best described as an opportunistic euryphagous carnivore. Euryphagous or generalist species are those that are able to subsist on a wide variety and size range of food types (Lagler et al. 1962, Gerking 1994, Moyle \& Cech 2000). Although M. ikei appeared to prefer crustaceans, $>30$ other species were also consumed including mammals, insects and reptiles from both aquatic and terrestrial habitats. Similarly, a large size range of items were evacuated from both large and small individuals, ranging from small items such as insect larvae, to large fish such as the freshwater mullet Myxus petardi (Castelnau). Whilst many generalist species adopt an omnivorous feeding strategy (Schoener 1971), this was not the case with $M$. ikei. Only small numbers of plankton and no plant material were evacuated from M. ikei, confirming the carnivorous nature of the species.

The stomach contents of Maccullochella ikei indicate that the species may be more a generalist forager rather than a specialised ambush opportunist as previously thought (Rowland 1993, Harris \& Rowland 1996). Radio-tracking studies of adult $M$. ikei in the
Mann River generally support this hypothesis, with the species reported to increase the size of its home range and use shallower habitats at night, undertaking what was believed to be foraging activities (Butler 2001, 2009). However, the ontogenetic shift in dietary preference of $M$. ikei indicates that the species may also shift foraging tactics as they grow. The diet of $M$. ikei $\leq 350 \mathrm{~mm}$ was typical of a benthic grazer (Lagler et al. 1962), with most individuals in this size class consuming food items such as insect larvae, shrimp and prawns from the benthos. In contrast, larger $M$. ikei, whilst still seemingly using a foraging strategy to gather their food, appeared to shift more to random opportunistic predatory behaviour, taking food items more likely found in mid-water and surface waters than in benthic environments, including large fish (e.g. Myxus petardi) and terrestrial animals (e.g. Mus musculus).

While there was clear evidence of an ontogenetic shift in dietary intake by Maccullochella ikei, individuals across all size categories consumed food items that were disproportionately small in comparison to their overall physical size and large gape. At its simplest, optimal foraging theory proposes that when predators are foraging, the net energy gained must be equal to or greater than that expended in collecting and processing a food item (Werner et al. 1983a,b, McIvor \& Odum 1988, Mittlebach 2002, Turesson et al. 2002). Optimal foraging therefore generally requires a shift in the food type consumed as overall body size increases, with larger individuals theoretically consuming proportionally larger food items (Sagar \& Eldon 1983, Werner et al. 1983a, Clapp et al. 1990, Beauchamp \& Van Tassell 2001). While there are many caveats when considering whether an individual is foraging optimally, one that may explain the behaviour of $M$. ikei in the present study is that decreased selectivity can occur when preferential food items are in low abundance (Schoener 1971, Pyke 1984). Butler \& Rowland (2008) suggested that food might be scarce at times in the Mann and Nymboida Rivers for large predatory fish such as $M$. ikei, due to the relatively poor nutrient status and discontinuous and dynamic nature of the system. It is therefore possible that while larger food items may be preferred by bigger M. ikei, they may not always be available or as easily caught, necessitating the uptake of smaller and potentially less optimal prey.

The dietary habits of Maccullochella ikei are similar to those reported for Australia's other freshwater cod taxa but were also subtly different. As with $M$. ikei, Baumgartner (2007) and Ebner (2006) reported 
a preference by $M$. peelii for macro-crustaceans such as freshwater shrimp and prawns, and for a variety of fish species. Similarly, Baumgartner (2007) found that trout $\operatorname{cod} M$. macquariensis (Cuvier) also preferred primarily macro-crustaceans, with small numbers of insects and molluscs also consumed. However, neither $M$. peelii nor $M$. macquariensis demonstrated the same predilection for the diversity of terrestrial and aquatic food items consumed by $M$. ikei in the present study. The diverse diet of M. ikei further supports the hypothesis that optimal food items may be limited at times in the Mann and Nymboida Rivers, compelling individuals to consume a greater variety of items to satisfy their energy requirements.

The seasonal shift in diet of Maccullochella ikei observed in the present study has not previously been described for any of Australia's other freshwater cod species; however, significant temporal variation has been found in the dietary composition of other freshwater fish (e.g. Knutsen et al. 2001, Pope et al. 2001, Liao et al. 2002). Whilst any number of factors can bring about temporal shifts in the diet of fish, it is the rate of encounter between predator and prey that ultimately dictates dietary choice (Schoener 1971, Mittlebach 2002, Floeter \& Temming 2003). Given that $M$. ikei is non-migratory (Butler 2009), any changes in diet are therefore likely a result of external factors. This is highlighted by the presence of distinct or increased numbers of certain food items in the diet of M. ikei in different seasons. Examples of this include Mus musculus, which were only collected in winter samples when they are expected to be at their highest abundance following their peak breeding period in late summer and autumn (Saunders \& Giles 1977), and an increase in the presence of aquatic insect larvae such as Hemicordulia spp. in summer as would be expected (Hawking \& New 2002).

Whilst changes in the seasonal availability of certain food items may have influenced forage selection by Maccullochella ikei, other less obvious factors may have also influenced its diet. Within the Mann and Nymboida Rivers, there are at times large numbers of diadromous fish species such as Australian bass Macquaria novemaculeata (Steindachner), Myxus petardi and freshwater herring Potamalosa richmondia (Macleay) (Allen et al. 2003). Although always present in the Mann and Nymboida Rivers, the localised abundance of these species is dictated by seasonal migration patterns, and also by whether river discharge has been sufficient to allow return upstream passage (Bonetti 2010). However, despite the likelihood of encountering these species in the diet of $M$. ikei, only $1 M$. petardi was recovered from the 268 gut samples collected, and no $M$. novemaculeata or $P$. richmondia. Whilst the absence of these species may be related in part to optimal foraging tactics, with all 3 fish being fast-swimming and potentially difficult to catch, other downstream influences may also have contributed. The Clarence Gorge is a long and complex series of waterfalls and cascades downstream of all sites sampled in the present study, and is known to influence the fish assemblages across the Clarence catchment as a whole (Bonetti 2010) (Fig. 1). Given that there were generally no differences in the diet of $M$. ikei between sites within seasons, it seems likely that the Clarence Gorge may be having more of an effect on the piscivorous diet of $M$. ikei than any of the barriers within the study area, including the Nymboida Weir. Stockwell et al. (2004) suggested that similar issues may be occurring for the critically endangered Mary River cod Maccullochella mariensis (Rowland), with downstream barriers restricting upstream passage of species such as $M$. petardi, which were thought to potentially have been an important food source for the species in the past.

With many endangered animals, the issues that result in a species becoming threatened and in its ongoing conservation can often appear to be speciesspecific and have little connectivity to ecosystem management in a wider context (Simberloff 1998). While this could be considered the case with Maccullochella ikei, a number of aspects of its dietary habits could be considered to play a significant role across broader scales. In freshwater food webs, the role of the riparian zone is more often seen as that of a contributor to primary production (Thorp \& Delong 1994), rather than that of a direct source of food items other than fruits and leaves for herbivores and terrestrial invertebrates for smaller fish species (Pusey \& Arthington 2003). However, for M. ikei, the riparian zone also provided food items in the form of secondary consumers such as large mammals and birds, which use these areas for breeding, shelter and feeding. This apparent dependence on the riparian zone as a source of food items for $M$. ikei not only adds a unique dimension to the need to protect and enhance these environments, but also reinforces the fact that there is a need to fully understand the biology of a species, including its dietary habits, to ensure effective management.

The stomach evacuation techniques used in the present study proved to be an effective means of determining the diet of Maccullochella ikei. Other stud- 
ies employing similar techniques have reported the successful and consistent evacuation of food items from gut-flushed fish with relatively low mortalities, as was the case in this study (e.g. Hakala \& Johnson 2004, Wanner 2006, Baumgartner 2007). The efficacy of the technique was also demonstrated in the present study by the low numbers of $M$. ikei that died during sampling, the small number of food items remaining in the stomachs of those individuals that died or were retained for validation purposes, and by the observed long-term survival of individuals up to $553 \mathrm{~d}$ after being gut flushed.

The present study has revealed that Maccullochella ikei displays high plasticity in seasonal dietary selection and that it most likely changes diet and foraging tactics as it grows. The forage items selected by M. ikei appeared to not always be of an optimal size for what is considered such a large and aggressive predator. It also seems that the numerous natural and anthropogenic fish-passage barriers found throughout the Mann and Nymboida Rivers may have less of an effect on the overall diet of M. ikei than the natural downstream barrier, the Clarence Gorge. Finally, while the issues affecting M. ikei initially appear to be localised, many have context on a larger global scale. Overall, the present study has provided a better understanding of the feeding ecology of one of Australia's most endangered fish species. This will not only assist in the enhancement of remnant populations of the species, but will provide an insight into the likely success of re-establishing populations in areas where the species has previously become extirpated.

Acknowledgements. The present study is from $\mathrm{PhD}$ research undertaken by G.L.B. and was supported by Southern Cross University, NSW Department of Primary Industries, the Australian Research Council (No. LP0347163) and Rous Water. All sampling was undertaken in accordance with the Australian Code of Practice for the Care and Use of Animals for Scientific Purposes (Permit No: 04/12). We thank J. Knight, R. Jarling, S. Rowland, T. Rowland and R. Predo for their help with field work, and S. Ingleby, C. McGregor, J. Hawking, L. Smith, I. Loch and A. Bolton for their help in identifying the various food items. Thanks also to S. Rowland, P. Baverstock, L. Cameron and the various people who commented and helped in the preparation of drafts of the manuscript.

\section{LITERATURE CITED}

Allen GR, Midgley SH, Allen M (2003) Field guide to freshwater fishes of Australia. CSIRO Publishing, Melbourne

Anderson MJ, Gorley RN, Clarke KR (2008) PERMANOVA + for PRIMER: guide to software and statistical methods. PRIMER-E, Plymouth
Anonymous (2000) Environmental monitoring of the regional water supply scheme: pilot study and long-term monitoring final report. Report to the Clarence County Council Regional Water Authority. The Ecology Lab Pty, Sydney

Anonymous (2004) Eastern freshwater cod (Maccullochella ikei) recovery plan. New South Wales Fisheries, Nelson Bay

Anonymous (2006) Habitat rehabilitation for the endangered eastern freshwater cod (Maccullochella ikei) in the Richmond River Catchment and trout cod (Maccullochella macquariensis) in the Murray Catchment, NSW. Report to the New South Wales Environmental Trust. New South Wales Department of Primary Industries, Sydney

Baumgartner LJ (2007) Diet and feeding habits of predatory fishes upstream and downstream of a low-level weir. J Fish Biol 70:879-894

Beauchamp DA, Van Tassell JJ (2001) Modeling seasonal trophic interactions of adfluvial bull trout in Lake Billy Chinook, Oregon. Trans Am Fish Soc 130:204-216

Bonetti R (2010) Catadromous fish migration across waterfalls: hydrological and hydraulic assessment of fish passage through the Clarence River gorge, NSW, Australia. BSc thesis, University of Wollongong

Boonstra R, Krebs CJ, Stenseth NC (1998) Population cycles in small mammals; the problem of explaining the low phase. Ecology 79:1479-1488

Bowen SH (1996) Quantitative description of the diet. In: Murphy BR, Willis DW (eds) Fisheries techniques, 2nd edn. American Fisheries Society, Bethesda, MD, p 513-532

Butler GL (2001) Age, growth and telemetric tracking of the eastern freshwater cod, Maccullochella ikei (Pisces: Percichthyidae), within the Mann-Nymboida River System, NSW. BSc thesis, Southern Cross University, Lismore

Butler GL (2009) Biology and conservation of the endangered eastern freshwater cod Maccullochella ikei Rowland. PhD dissertation, Southern Cross University, Lismore

> Butler GL, Rowland SJ (2008) Using traditional age and growth techniques in endangered species management: eastern freshwater cod, Maccullochella ikei. Mar Freshw Res 59:684-693

> Butler GL, Rowland SJ (2009) Using underwater cameras to describe the reproductive behaviour of the endangered eastern freshwater cod Maccullochella ikei. Ecol Freshw Fish 18:337-349

Chipps SR, Garvey JE (2007) Assessment of diets and feeding patterns. In: Guy CS, Brown ML (eds) Analysis and interpretation of freshwater fisheries data. American Fisheries Society, Bethesda, MD, p 473-514

> Clapp DF, Clark RD, Diana JS (1990) Range, activity and habitat of large, free-ranging brown trout in a Michigan stream. Trans Am Fish Soc 119:1022-1034

> Drewe KE, Horn MH, Dickson KA, Gawlicka A (2004) Insectivore to frugivore: ontogenetic changes in gut morphology and digestive enzyme activity in the characid fish Brycon guatemalensis from Costa Rican rain forest streams. J Fish Biol 64:890-902

> Duffy DC, Jackson S (1986) Diet studies of seabirds: a review of methods. Colon Waterbirds 9:1-17

> Ebner B (2006) Murray cod an apex predator in the Murray River, Australia. Ecol Freshw Fish 15:510-520

> Falautano M, Castriota L, Grazia MF, Andaloro F (2007) 
Feeding ecology of little tunny Euthynnus alletteratus in the central Mediterranean Sea. J Mar Biol Assoc UK 87: 999-1005

Ferguson R, Lampert G, Brierley G (1999) River Styles ${ }^{\mathrm{TM}}$ in the Clarence Catchment, North Coast, NSW. Department of Physical Geography, Macquarie University, Sydney

> Floeter J, Temming A (2003) Explaining diet composition of North Sea cod (Gadus morhua): prey size preference vs. prey availability. Can J Fish Aquat Sci 60:140-150

Gerking SD (1994) Feeding ecology of fish. Academic Press, San Diego, CA

> Hakala JP, Johnson FD (2004) Evaluation of gastric lavage method for use on largemouth bass. N Am J Fish Manag 24:1398-1403

Harris JH, Rowland SJ (1996) Australian cods and basses. In: McDowall R (ed) Freshwater fishes of south-eastern Australia. Reed Books, Sydney, p 150-163

> Hawking JH, New TR (2002) Interpreting dragonfly diversity to aid in conservation assessment: lessons from the Odonata assemblage at Middle Creek, north-eastern Victoria, Australia. J Insect Conserv 6:171-178

> Joyce WN, Campana SE, Natanson LJ, Kohler NE, Pratt HI, Jensen CF (2002) Analysis of stomach contents of the porbeagle shark (Lamna nasus Bonnaterre) in the northwest Atlantic. ICES J Mar Sci 59:1263-1269

Kamler JF, Pope KL (2001) Nonlethal methods of examining fish stomach contents. Rev Fish Sci 9:1-11

Knutsen JA, Knutsen H, Gjosaeter J, Jonsson B (2001) Food of anadromous brown trout at sea. J Fish Biol 59:533-543

Lagler KF, Bardach JE, Miller RR (1962) Ichthyology: the study of fishes. John Wiley \& Sons, Sydney

> Liao H, Pierce CL, Larscheid JG (2002) Diet dynamics of the adult piscivorous fish community in Spirit Lake, Iowa, USA 1995-1997. Ecol Freshw Fish 11:178-189

- McIvor CC, Odum WE (1988) Food, predation risk, and microhabitat selection in a marsh fish assemblage. Ecology 69:1341-1351

Meretsky VJ, Valdez RA, Douglas ME, Brouder MJ, Gorman OT, Marsh PC (2000) Spatio-temporal variation in length-weight relationships of endangered humpback chub: implications for conservation and management. Trans Am Fish Soc 129:419-428

Merrick RL, Chumbley MK, Byrd GV (1997) Diet diversity of Steller sea lions (Eumetopias jubatus) and their population decline in Alaska: a potential relationship. Can J Fish Aquat Sci 54:1342-1348

Mittlebach GG (2002) Fish foraging and habitat choice: a theoretical perspective. In: Hart PJB, Reynolds JD (eds) Handbook of fish biology and fisheries, Vol 1. Blackwell Science, Oxford, p 251-266

Moyle PB, Cech JJ (2000) Fishes: an introduction to ichthyology, 4th edn. Prentice Hall, Englewood Cliffs, NJ

Munkittrick KR, Dixon DG (1989) A holistic approach to ecosystem health assessment using fish population characteristics. Hydrobiologia 188-189:123-135

Munro RHM, Nielson SE, Price MH, Stenhouse GB, Boyce MS (2006) Seasonal and diel patterns of grizzly bear diet and activity in west-central Alberta. J Mammal 87: 1112-1121

Nielsen LA (1992) Methods of marking fish and shellfish. American Fisheries Society, Bethesda, MD

Olson NW, Paukert CP, Willis DW, Klammer JA (2003) Prey selection and diets of bluegill Lepomis macrochirus with differing population characteristics in two Nebraska natural lakes. Fish Manag Ecol 10:31-40

Petridis D, O'Hara K (1988) Assessment of diet in two cyprinids using a modified stomach-flushing technique. Aquac Fish Manag 19:63-68

$>$ Platell ME, Ang HP, Hesp SA, Otter IC (2007) Comparisons between the influences of habitat, body size and season on the dietary composition of the sparid Acanthopagrus latus in a large marine embayment. Estuar Coast Shelf Sci 72:626-634

Pusey BJ, Arthington AH (2003) Importance of the riparian zone to the conservation and management of freshwater fish: a review. Mar Freshw Res 54:1-16

Pope KL, Brown ML, Duffy WG, Michaletz PH (2001) A caloric-based evaluation of diet indices for largemouth bass. Environ Biol Fishes 61:329-339

Pyke GH (1984) Optimal foraging theory: a critical review. Annu Rev Ecol Syst 15:523-575

Reid K, Croxall JP (2001) Environmental response of upper trophic-level predators reveals a system change in an Antarctic marine ecosystem. Proc Biol Sci 268:377-384

Renones O, Polunin NVC, Goni R (2002) Size related dietary shift of Epinephelus marginatus in a western Mediterranean littoral ecosystem: an isotope and stomach content analysis. J Fish Biol 61:122-137

Rowland SJ (1985) Aspects of the biology and artificial breeding of the Murray cod, Maccullochella peeli, and the eastern freshwater cod, M. ikei sp. nov. (Pisces: Percichthyidae). PhD Dissertation, Macquarie University, Sydney

Rowland SJ (1989) Conservation of the eastern freshwater cod. In: Mears PT, Hennessy DW, Rowland SJ (eds) Grafton Agricultural Research and Advisory Station Research Report 1987-8. New South Wales Agriculture and Fisheries, Grafton, p 8-9

> Rowland SJ (1993) Maccullochella ikei, an endangered species of freshwater cod (Pisces: Percichthyidae) from the Clarence River system, NSW and $M$. peelii mariensis, a new subspecies from the Mary River system, QLD. Rec Aust Mus 45:121-145

Rowland SJ (1996) Threatened fishes of the world: Maccullochella ikei Rowland, 1985 (Percichthyidae). Environ Biol Fishes 46:350

Sagar PM, Eldon GA (1983) Food and feeding of small fish in the Rakaia River, New Zealand. NZ J Mar Freshw Res 17:213-226

Sakuragi M, Igota H, Uno H, Koichi K, Kaneko M, Akamatsu R, Maekawa K (2003) Benefit of migration in a female sika deer population in eastern Hokkaido, Japan. Ecol Res 18:347-354

> Santos MB, Clarke MR, Pierce GJ (2001) Assessing the importance of cephalopods in the diets of marine mammals and other top predators: problems and solutions. Fish Res 52:121-139

Saunders GR, Giles JR (1977) A relationship between plagues of the house mouse, Mus musculus (Rodentia: Muridae) and prolonged periods of dry weather in southeastern Australia. Aust Wildl Res 4:241-247

Schoener TW (1971) Theory of feeding strategies. Annu Rev Ecol Syst 11:902-914

> Simberloff D (1998) Flagships, umbrellas, and keystones: Is single-species management passé in the landscape era? Biol Conserv 83:247-257

Specziar A, Biro P, Tolg L (1998) Feeding and competition of five cyprinid fishes in different habitats of the Lake Balaton littoral zone, Hungary. Ital J Zool 65:331-336 
Stehlik LL, Meise CJ (2000) Diet of winter flounder in a New Jersey estuary: ontogenetic change and spatial variation. Estuaries 23:381-391

Stockwell B, Hutchison M, Wedlock B, Ford E, Anderson T, Thomson C, Stephens K (2004) Freshwater aquatic biodiversity in the Burnett-Mary region. Technical Report. Queensland Department of Primary Industries and Fisheries, Brisbane

Szepanski MM, Ben-David M, Van Ballenberghe V (1999) Assessment of anadromous salmon resources diet in the Alexander Archipelago wolf using stable isotope analysis. Oceanologia 120:1432-1439

Talbot B, Molloy S, Chapman R, Riches M (2004) The rivers to the sea: experiences with two endangered aquatic fish species. In: Hutchings P, Lunney D, Dickman C (eds) Threatened species legislation: Is it just an act? Royal Zoological Society of New South Wales, Mosman, p 125-134

Thorp JH, Delong MD (1994) The riverine productivity model: an heuristic view of carbon sources and organic matter processing in large river ecosystems. Oikos 70: 305-308

Turesson H, Persson A, Bronmark C (2002) Prey size selec-

Editorial responsibility: Steven Cooke,

Ottawa, Ontario, Canada tion in piscivorous pikefish (Stizostedion lucioperca) includes active prey choice. Ecol Freshw Fish 11: 223-233

Wanner GA (2006) Evaluation of gastric lavage method on juvenile pallid sturgeon. N Am J Fish Manag 26:587-591

Wassenaar LI, Hobson KA (1998) Natal origins of migratory monarch butterflies at wintering colonies in Mexico: new isotopes evidence. Proc Natl Acad Sci USA 95: 15436-15439

Werner EE, Gilliam JF, Hall DJ, Mittlebach GG (1983a) Experimental tests of optimal habitat use in fish: the role of relative habitat profitability. Ecology 64:1525-1539

- Werner EE, Gilliam JF, Hall DJ, Mittelbach GG (1983b) An experimental test of the effects of predation risk on habitat use in fish. Ecology 64:1540-1548

Williams SR, Karasov WH (2001) Phenotypic flexibility in digestive system structure and function in migratory birds and its ecological significance. Comp Biochem Physiol 128:579-593

> Yamagiwa J, Mwanza N, Yumoto T, Maruhashi T (1994) Seasonal change in the composition of the diet of eastern lowland gorillas. Primates 35:1-14

Submitted: June 8, 2011; Accepted: December 6, 2011

Proofs received from author(s): January 31, 2012 